\title{
Мария Сакаева
}

Natalia Roudakova. Losing Pravda: Ethics and the Press in Post-Truth Russia.
New York: Cambridge University Press, 2017. 265 pp. ISBN 978-1-31662-977-2.

\begin{abstract}
Мария Сакаева, кафедра философии и методологии образования, Ухтинский государственный технический университет. Адрес для переписки: УГтУ, ул. Сенюкова, 13, Ухта, Республика Коми, 169300, Россия. eu.sakaeva@gmail.com
\end{abstract}

Рецензия написана в рамках гранта немецкого фонда академических обменов ДААД.

Будущее независимой журналистики находится под угрозой по всей Европе, даже в странах с устоявшейся демократией (Selva 2020). Состояние американской журналистики, которая многие десятилетия была эталоном свободы, характеризуют как затянувшийся кризис (Coddington 2019; Usher 2016). Вердикт Натальи Рудаковой, вынесенный российской журналистике, тоже неутешительный, хотя причины упадка представляются автору разными. Книга «Потерянная истина: Этика и пресса в эпоху постправды в России» является первой серьезной попыткой переосмыслить историю становления, развития и упадка российской журналистики через культурологическую оптику. Взгляд автора на эту проблему отличается от существовавших ранее подходов к изучению масс-медиа и журналистики, использующих в основном инструменты политического и институционального анализа (Rollberg and Laruelle 2018).

Рудакова предлагает посмотреть на журналистику одновременно как на зеркало, в котором отразилась история страны последних тридцати лет, и как на мощную силу, которая в 1990-е годы подготовила условия для авторитарного поворота. По ее мнению, пафос свободы и демократии был ширмой, за которой долгие годы скрывались хищнические интересы основателей постсоветского медиарынка и их циничные убеждения (с. 220). С обозначенной позицией связано обоснование ключевого для книги понятия «истина». В русском языке слова «истина» и «правда» не тождественны, поскольку истина - едина, а правда - у каждого своя. Поэтому перевод слова truth как «истина» представляется мне более точным. Поиск истины (truth-seeking) и производство истины (truth-telling) являются главными задачами журналистики, а публичный характер этого процесса фундаментален для поддержания социально-политического порядка (с. 11). Одним из важнейших итогов исследования является вывод о том, что утрата свободы слова, деградация журналистики и сворачивание публичного пространства в 2000-2010-е годы стало результатом поступательного отказа журналистики 1990-х от поиска истины.

У книги много сильных сторон. Прежде всего это разнообразные источники эмпирических данных. В основу исследования лег метод гибридной этнографии: включенное наблюдение, полевые заметки, формальные и неформальные интервью (в общей сложности около сотни). Список источников включает архивные документы, биографии и воспоминания советских журналистов (для первых исто- 
рических глав), электронную переписку с участниками событий, правовые документы, газетные публикации и письма читателей, рекламные объявления. Описания социальной реальности в книге особенно убедительны в тех случаях, когда автор опирается на воспоминания и очерки советских журналистов и писателей. Основной корпус интервью и наблюдений для описания постсоветских реалий был собран в Нижнем Новгороде, дополнительные полевые материалы - в Москве и Казани (с. 125). Рудакова провела в поле в общей сложности два года: 20012002, осень 2008, осень-зима 2011-2012.

Вместе с тем отсылки к различным теориям, упомянутым в книге, не всегда выглядят обоснованными при анализе эмпирических данных. Так, во введении автор описывает актуальные теоретические дискуссии о роли журналистики, апеллируя к концепциям политической культуры, публичной политики, общественного блага, демократических институтов. В последующих главах и в заключении набор концепций растет за счет рассуждений о цинизме, юморе, пафосе, патетике, иронии и, наконец, о связи журналистики и проституции. В результате книга перегружена аналитическими конструкциями едва ли не всех ключевых социологов и философов XX века (Макс Вебер, Жиль Делез, Мишель Фуко, Ханна Арендт). При этом не всегда убедительна и очевидна связь между их идеями, журналистикой в целом и российской журналистикой в частности.

Тем не менее, книга Рудаковой занимает особое место в мировой академической литературе о журналистике и публичной сфере как минимум по двум причинам. Во-первых, она подвергает критике устоявшуюся в литературе оппозицию между капитализмом и социализмом, основанную на идее о том, что при социализме пресса обслуживает интересы государства. Отсутствие рынка, утверждает Рудакова, не означает отсутствия субъектности, общественного авторитета и политического влияния журналистов. Книга начинается с тезиса о том, что, будучи формально зависимой от партии, советская пресса обладала автономией и принуждала государство к публичности. Более того, именно советская пресса была главным инструментом защиты интересов советских граждан перед лицом государства (с. 32, 218). В этом смысле работа Рудаковой является первым академическим исследованием, которое реабилитирует советскую прессу. В то же время она дополняет ту более широкую дискуссию в постсоветских исследованиях, которая предлагает пересмотреть отношение к социализму как к миру абсолютного зла (Юрчак 2014).

Второе новшество, которое Рудакова вносит в дебаты о российской и мировой журналистике, - это обсуждение национальных особенностей постсоциалистического транзита. Этому посвящена вторая глава книги. Для стран Восточной Европы и Балтии транзит стал возвращением в Европу, поэтому медийный рынок и журналистское сообщество этих стран довольно легко усвоили новые правила игры, включились в устоявшиеся институты рынка и гражданского общества (с. 119). Поставторитарный транзит оказался менее болезненным и для Латинской Америки, Южной Европы и Восточной Азии, поскольку капитализм там уже существовал (с. 98). В начале 1990-х советская журналистика, как и все общество, практически в одночасье сделала шаг в никуда: социализма уже не было, знакомство с рыночной экономикой и капитализмом только предстояло. 
И здесь я перехожу к этическим претензиям к российскому капитализму, которые рассмотрены в книге. В этом отношении «Потерянная истина» образует неожиданный дуэт с давней монографией журналиста Пола Хлебникова (2001), поскольку поднимает вопрос о не экономической, не материальной и не поддающейся количественной оценке цене постсоветского транзита России. Ценой перехода, по мнению обоих авторов, стало игнорирование ценностно-нормативных и культурно-этических основ социального развития. Третья глава книги содержит анализ тех причин, по которым на руинах советской прессы так и не возникла журналистика как полноценный, устойчивый демократический и публичный институт, главная функция которого состоит в защите общественных интересов. В качестве основной причины автор обозначает отказ от социально-этической ценности «правдоискательства» и одержимость российской журналистики капиталистической логикой. С одной стороны, журналисты вынуждены были постоянно думать об источниках заработка, поэтому вопрос профессиональной этики и поиск истины как смысл журналистской деятельности довольно скоро утратили свою ценность (с. 117). С другой стороны, владельцы медийного бизнеса были одержимы жаждой наживы. Апогеем коммерциализации стала война компроматов второй половины 1990-х годов, когда по всей стране пресса обслуживала интересы предвыборных кампаний и политических машин (с. 136).

Анализу компромата посвящена третья - ключевая, на мой взгляд, - глава книги. Рудакова подчеркивает, что производство компромата вместо поиска истины стало логическим следствием погони медийного бизнеса за прибылью. Компромат был целью, средством и смыслом существования журналистики. Тем самым журналисты и СМИ запустили необратимый процесс депрофессионализации и раскола журналистского сообщества. Один из главных выводов исследования: война компроматов стала апогеем «приватизации» журналистики, когда частные акторы захватили территорию публичного в атмосфере продолжительной моральной и институциональной неопределенности и отсутствия четких границ между частным и публичным, государственным и общественным (с. 123). Такая трактовка трансформации постсоветской журналистики ставит работу Рудаковой в один ряд с теми исследователями постсоциализма, которые рассматривают приватизацию разных сфер постсоветского общества как социально-культурный и моральноэтический феномен (Verdery 1996).

Этот взгляд на приватизацию тесно связан с вопросом о коллективной ответственности журналистов и СМИ за авторитарный поворот в новой России. Рудакова опровергает распространенный взгляд на независимую журналистику как на жертву кремлевского молоха (Rollberg and Laruelle 2018). Этому посвящена четвертая глава о цинизме и журналистике, где цинизм рассматривается как фундаментальное явление российского общества в «эпоху Путина». Автор показывает, как и почему цинизм стал главным принципом политического управления и социальной повседневности, основой функционирования СМИ вне зависимости от формы собственности и идеологического ракурса. Неслучайно в книге отсутствует само понятие «независимая журналистика». Тем самым автор присоединяется к ведущим исследователям журналистики в мировой академии, которые показы- 
вают аналитическую беспомощность и концептуальную бесполезность этой метафоры для понимания места журналистики в современном мире. Искусственность дискуссии о независимой журналистике все более очевидна на фоне реальности с размытыми границами между государством и бизнесом, между экономической природой и социальными функциями медийного бизнеса (Coddington 2019; Zelizer 2004). Рудакова также намеренно не вступает в дискуссию об отраслевом профиле российской журналистики (политическая, экономическая и так далее), поскольку ставит другую задачу - понять влияние постсоветской журналистики на формирование публичной сферы.

И главный вывод книги в этой связи неутешительный: увлекшись игрой в рынок, выбрав капиталистическую логику денег и власти в качестве основы, журналистика лишила себя институциональной власти и общественного авторитета (с. 220). Журналисты и издания «допутинской России» способствовали деморализации российского общества, отдав свободу слова на откуп федеральным олигархам и региональным бизнес-группам (с. 127, 156). Иными словами, монетизация truthseeking и truth-telling сыграла непоследнюю роль в том, что демократия в России проиграла. Рудакова проводит параллели между советским социализмом и западным либерализмом, поскольку от российского капитализма их отличало наличие консолидированного, профессионального журналистского сообщества. Оно представляло интересы публичного перед лицом государства в Советской России и в странах западной демократии (с. 218). В России влиятельные группы так увлеклись дискредитацией коммунизма и отрицанием прошлого, что не заметили или предпочли не заметить, к каким катастрофическим последствиям привела победа частных интересов над общественным благом в войне между прагматикой капитализма и либеральными идеалами свободы прессы (с. 225).

Метафора войны неслучайно возникает в заключении книги. Общественные и академические дискуссии о месте журналистики и роли медиа в сегодняшней России давно напоминают военные сражения. Противоборствующие стороны (условно: журналисты и пропагандисты, так называемые государственные и независимые (МИ) не просто избегают критической оптики - они игнорируют главный вопрос о коллективной ответственности за смерть журналистики, фрагментацию и поляризацию российского общества. Выход книги со словом post-truth в заглавии в 2017 году оказался символичным, поскольку именно «постправда» стала словом 2016 года по версии Оксфордского словаря. Но дело не столько в словах.

Если журналистика становится просто бизнесом без вмешательства убеждений и принципов, тогда говорить о журналистике уже не приходится (с. 204). Если все выдается за правду, то уже ничто не воспринимается как правда (с. 223). Если факты сводятся к мнениям, а мнения выдаются за факты, то за лозунгами о свободе слова уже нет содержания. Размывание границ между фактами и мнениями, между политическим, профессиональным и моральным началось задолго до государственного прессинга. В результате проиграли все: СМИ и аудитория, общество и журналистика. Метафору о российских СМИ как о поле игры, где нет победителей, я бы отнесла к рамке, принципиально важной для дальнейшего разговора о настоящем и будущем российской журналистики. 


\section{СПИСОК ЛИТЕРАТУРЫ}

Хлебников, Пол. 2001. Крестный отец Кремля Борис Березовский, или История разграбления России. М.: Детектив-Пресс.

Юрчак, Алексей. 2014. Это было навсегда, пока не кончилось: Последнее советское поколение. М.: Новое литературное обозрение.

Coddington, Mark. 2019. Aggregating the News: Secondhand Knowledge and the Erosion of Journalistic Authority. New York: Columbia University Press.

Rollberg, Peter, and Marlene Laruelle, eds. 2018. Mass Media in the Post-Soviet World: Market Forces, State Actors, and Political Manipulation in the Informational Environment after Communism. Stuttgart, Germany: Ibidem Verlag.

Selva, Meera. 2020. Fighting Words: Journalism under Assault in Central and Eastern Europe. 0xford: Reuters Institute for the Study of Journalism, University of Oxford. https://bird.tools/wp -content/uploads/2020/01/MSelva-Journalism_Under_Assault_FINAL_0.pdf.

Usher, Nikki. 2016. Interactive Journalism: Hackers, Data, and Code. Urbana: University of Illinois Press.

Verdery, Katherine. 1996. What Was Socialism, and What Comes Next? Princeton, NJ: Princeton University Press.

Zelizer, Barbie. 2004. Taking Journalism Seriously: News and the Academy. London: SAGE. 